JURNAL ILMIAH

\title{
PENGARUH PIJAT (MASSAGE) TERHADAP PERUBAHAN INTENSITAS NYERI REMATIK PADA LANSIA DI DESA KERTAPATI PUSKESMAS DUSUN CURUP BENGKULU UTARA
}

\author{
Feny Marlena ${ }^{1}$, Rita Juniarti ${ }^{2}$ \\ Program Studi Ilmu Keperawatan, Stikes Bhakti Husada Bengkulu ${ }^{1,2}$ \\ e-mail:fenymarlena@yahoo.com ${ }^{1}$ \\ ritajuniarti@gmail.com ${ }^{2}$
}

\begin{abstract}
ABSTRAK
Tujuan penelitian adalah untuk mengetahui pengaruh pijat (massage) terhadap intensitas nyeri rematik pada lansia di desa Kertapati Puskesmas Dusun Curup Bengkulu Utara. Penelitian ini merupakan penelitian kuantitatif menggunakan rancangan penelitian quasi eksperiment dengan desain penelitian pre dan post test design. Sampel dalam penelitian ini berjumlah 10 orang yang diambil dengan teknik purposive sampling. Analisis yang digunakan adalah analisis univariat dan analisis bivariat, uji statistik yang digunakan yaitu uji t-dependen. Hasil Penelitian, rata-rata nilai nyeri rematik sebelum dilakukan intervensi pijat (massage) pada lansia di desa Kertapati Puskesmas Dusun Curup Bengkulu Utara adalah 5,2 dan sesudah intervensi adalah adalah 3,4. Hasil uji $t$-dependen didapatkan ada perbedaan secara signifikan nilai nyeri sebelum dan sesudah intervensi pijat (massage) dengan $\rho$ value 0,000. Kesimpulan, ada pengaruh pijat (massage) terhadap intensitas nyeri rematik pada lansia di Desa Kertapati Puskesmas Dusun Curup Bengkulu Utara. Diharapkan dapat memberikan asuhan keperawatan yang optimal terutama intervensi pijat (massage) kepada lansia serta dapat mensosialisasikan keterampilan pijat (massage) kepada para lansia, sehingga mereka dapat secara mandiri melakukan pijat bila ada serangan nyeri.
\end{abstract}

Kata Kunci: Lansia, Nyeri Reumatik, Pijat (Massage)

\begin{abstract}
The purpose of this study was to determine the effect of massage on the intensity of rheumatic pain in the elderly in the village of Kertapati, Puskesmas, Dusun Curup, North Bengkulu. This research is a quantitative study using a quasi experimental research design with pre and post test design research designs. The sample in this study amounted to 10 people taken by purposive sampling technique. The analysis used is univariate analysis and bivariate analysis, the statistical test used is the $t$-dependent test. The results of the study, the average value of rheumatic pain before a massage intervention (massage) in the elderly in the village of Kertapati, Curup Hamlet North Bengkulu is 5.2 and after the intervention is 3.4. T-dependent test results found that there were significant differences in the value of pain before and after massage intervention (massage) with a value of 0,000. In conclusion, there is an effect of massage on the intensity of rheumatic pain in the elderly in the village of Kertapati, Puskesmas, Dusun Curup, North Bengkulu. It is expected to provide optimal nursing care, especially massage interventions to the elderly and can socialize massage skills to the elderly, so that they can independently massage when there is a pain attack.
\end{abstract}


Keywords: Elderly, Rheumatic Pain, Massage

\section{PENDAHULUAN}

Masalah-masalah kesehatan akibat penuaan terjadi pada berbagai sistem tubuh, salah satunya adalah penyakit rematik. Reumatik adalah penyakit inflamasi non- bakterial yang bersifat sistemik, progesif, cenderung kronik dan mengenai sendi serta jaringan ikat sendi secara simetris (Chairuddin, 2008).

Rematik adalah penyakit yang menyerang anggota tubuh yang bergerak yaitu bagian tubuh yang berhubungan antara yang satu dengan yang lain dengan perantaraan persendian, sehingga menimbulkan rasa nyeri. Semua jenis rematik menimbulkan rasa nyeri yang mengganggu terutama pada hambatan dalam bekerja maupun melaksanakan kegiatan sehari-hari sehingga dapat menimbulkan gangguan psikososial seperti kecemasan pada penderita dan keluarga (Nugroho \& Wahyudi, 2012).

Berdasarkan hasil penelitian terakhir dari Zeng (2008), prevalensi nyeri rematik di Indonesia mencapai $23,6 \%$ hingga $31,3 \%$. Angka ini menunjukkan bahwa rasa nyeri akibat rematik sudah cukup mengganggu aktivitas masyarakat Indonesia, terutama mereka yang memiliki aktivitas sangat padat di daerah perkotaan seperti mengendarai kendaraan di tengah arus kemacetan, duduk selama berjam-jam tanpa gerakan tubuh yang berarti, tuntutan untuk tampil menarik dan prima, kurangnya porsi berolah raga, serta faktor bertambahnya usia.

American collage Rheumatology mengemukakan bahwa penanganan untuk nyeri rematik dapat meliputi terapi farmakologi dan nonfarmakologi. Teknik nonfarmakologi yang dapat digunakan untuk mengurangi nyeri pada penderita rematik diantaranya yaitu dengan pijat, kompres panas atau dingin, stimulasi elektrik saraf kulit transkutan, teknik relaksasi dan istirahat. Tindakan nonfarmakologi juga dapat dikerjakan dirumah dan caranya sederhana. Selain itu tindakan nonfarmakologi juga dapat digunakan sebagai pertolongan pertama ketika nyeri menyerang (Anas, 2009).

Berdasarkan data yang diperoleh Peneliti di Desa Kertapati Puskesmas Dusun Curup Bengkulu Utara bahwa pada tahun 2016 terdapat 28 orang lansia mengalami Rematik dan tahun 2017 meningkat menjadi 40 orang. Survey awal yang peneliti lakukan pada bulan Desember tahun 2017 melalui wawancara terhadap 7 orang lansia yang mengalami rematik pada saat itu sedang memeriksakan kesehatannya di puskesmas Dusun Curup, mereka mengatakan bahwa mereka sering mengalami nyeri sendi pada kaki dan saat sehabis melakukan aktivitas berat atau saat pagi habis bangun tidur. Dan hampir semua para penderita reumatik jika penyakitnya kambuh mereka hanya minum analgesik yang diberikan dari petugas puskesmas setempat. Sedangkan terapi pijat (massage) tidak pernah dilakukan di rumah karena takut dan tidak ada pengetahuan tentang pijat (massage).

Tujuan penelitian ini adalah diketahuinya pengaruh pijat (massage) terhadap intensitas nyeri rematik pada lansia di Desa Kertapati Puskesmas Dusun Curup Bengkulu Utara.

\section{METODE PENELITIAN}

Jenis penelitian yang digunakan adalah quasi eksperiment menggunakan pre dan post test design dengan pemberian pijat punggung/back massage pada lansia. Dalam rancangan ini perlakuan akan dilakukan (X), kemudian dilakukan pengukuran (observasi) atau pre $(\mathrm{O} 1)$ dan post test $(\mathrm{O} 2)$. Populasi dari penelitian ini adalah lansia di Desa Kertapati Puskesmas Dusun Curup Bengkulu Utara pada tahun 2017, 
berjumlah 40 orang. Sampel yang akan diteliti berjumlah 10 orang, menggunakan tehnik purposive sampling. Data yang digunakan dalam penelitian ini merupakan data primer dan data sekunder. Untuk melihat pengaruh antara dua variabel kategori maka digunakan uji t-dependen. Prosedur dalam penelitian ini adalah, perlakuan message (pijatan) yang dilakukan hanya satu kali selama 20-30 menit.

\section{HASIL PENELITIAN}

Tabel 1.

Pengaruh Pijat (Massage) Terhadap Intensitas Nyeri Rematik Pada Lansia Di

Desa Kertapati Puskesmas Dusun Curup Bengkulu Utara

\begin{tabular}{llccc}
\hline \multicolumn{1}{c}{ Variabel } & N & Mean & Std. Deviasi & $\begin{array}{c}\text { P } \\
\text { value }\end{array}$ \\
\hline $\begin{array}{l}\text { Skala nyeri } \\
\text { rematik } \\
\text { sebelum }\end{array}$ & & 5,2 & 0,789 & \\
dilakukan & & & & \\
pijat/massage & & & & \\
\cline { 1 - 3 } $\begin{array}{l}\text { Skala nyeri } \\
\text { rematik }\end{array}$ & 10 & 3,4 & 1,075 & \\
$\begin{array}{l}\text { sesudah } \\
\text { dilakukan } \\
\text { pijat/massage }\end{array}$ & & & & \\
\hline
\end{tabular}

Berdasarkan tabel 1 di atas dapat diketahui bahwa nilai rata-rata nyeri rematik sebelum dilakukan pijat/massage pada lansia adalah 5,2 dengan standar deviasi 0,789 dan nilai rata-rata nyeri rematik sesudah dilakukan pijat/massage pada lansia adalah 3,4 dengan standar deviasi 1,075 . Artinya terjadi penurunan skala nyeri rematik pada lansia yakni dari 5,2 menjadi 3,4. Hasil uji statistic uji $t$ dependen didapatkan nilai $\rho$ value 0,000 $(\alpha$ 0,05) maka dapat disimpulkan bahwa ada pengaruh secara signifikan pijat (massage) terhadap intensitas nyeri rematik pada lansia di Desa Kertapati Puskesmas Dusun Curup Bengkulu Utara.

\section{PEMBAHASAN}

Hasil analisa peneliti bahwa terjadi penurunan skala nyeri pada lansia rematik setelah dilakukan massage (pijit). Hal ini berarti massage (pijit) merupakan salah satu terapi yang dapat diberikan kepada lansia untuk mengurangi rasa nyeri yang dialami lansia. Efektivitas massage (pijit) terhadap skala nyeri tersebut disebabkan oleh pengaruh distraksi dan meningkatnya hormon endorphin dari efek relaksasi yang ditimbulkan oleh massage (pijit), sehingga mampu memberikan efek kenyamanan pada lansia.

Peneliti juga berasumsi bahwa penurunan jumlah ini dipengaruhi oleh adanya faktor psikologis, dimana dengan memberikan perhatian yang lebih dapat juga menurunkan sensasi nyeri yang bersifat subyektif yang dirasakan oleh klien. Mereka yang berusia lanjut akan kembali kepada masa seperti saat balita dimana mereka membutuhkan perhatian, kasih sayang yang lebih.

Hal ini sesuai dengan yang dikemukakan Potter dan Perry (2012), bahwa respon nyeri seseorang dipengaruhi oleh usia, jenis kelamin, budaya, perhatian, makna nyeri, gaya koping yang digunakan, kecemasan dan stressor lain. Lingkungan dan dukungan orang terdekat, pengalaman nyeri yang lalu.

Faktor lain yang bermakna mempengaruhi respon nyeri adalah kehadirn orang-orang terdekat klien dan bagaimana sikap mereka terhadap klien. Individu yang mengalami nyeri seringkali bergantung pada anggota keluarga atau teman dekat untuk memperoleh dukungan, bantuan dan perlindungan. Dengan memberikan perhatian kepada lansia dapat membuat lansia merasa nyaman dan mempengaruhi respon nyeri yang dirasakan.

Mekanisme penurunan nyeri ini dapat dijelaskan dengan teori gate control yaitu intensitas nyeri diturunkan dengan dengan memblok transmisi nyeri pada 
gerbang (gate) dan teori Endorphin yaitu menurunnya intensitas nyeri dipengaruhi oleh meningkatnya kadar endorphin dalam tubuh. Dengan pemberian terapi massage dapat merangsang serabut A beta yang banyak terdapat di kulit dan berespon terhadap massage ringan pada kulit sehingga impuls dihantarkan lebih cepat.

Pemberian stimulasi ini membuat masukan impuls dominan berasal dari serabut A beta sehingga pintu gerbang menutup dan impuls nyeri tidak dapat diteruskan ke korteks serebral untuk diinterpretasikan sebagai nyeri (Guyton \& Hall, 2009). Di samping itu, sistem kontrol desenden juga akan bereaksi dengan melepaska endorphin yang merupakan morfin alami tubuh sehingga memblok transmisi nyeri dan persepsi nyeri tidak terjadi (Potter \& Perry, 2012), jadi intensitas nyeri yang dirasakan mengalami penurunan.

\section{KESIMPULAN}

Berdasarkan hasil renelitian
tentang pengaruh pijat $\begin{array}{r}\text { penassage) } \\ \text { (mata }\end{array}$
terhadap intensitas nyeri rematik pada
lansia di Desa Kertapati Puskesmas
Dusun Curup Bengkulu Utara,
disimpulkan ada pengaruh pijat
(massage) terhadap intensitas nyeri
rematik pada lansia di Desa Kertapati
Puskesmas Dusun Curup Bengkulu Utara
$(\mathrm{p}=0,000)$.

\section{SARAN}

Demi meningkatkan keilmuan dan mutu pendidikan keperawatan, diharapkan perlunya untuk memperhatikan pengembangan informasi dan keterampilan mahasiswa dalam memberikan asuhan keperawatan pada penderita rematik khususnya keterampilan dalam memberikan intervensi pijat (massage). Untuk peneliti selanjutnya harus dapat mengembangkan teori-teori tentang nyeri rematik yang dialami oleh lansia dan memberikan solusi lain yang bermanfaat selain pijat (massage), misalnya tentang teknik nonfarmakologis lainnya untuk penurunan sensasi nyeri sendi antara lain: imajinasi terbimbing, Bio fed back, kompres parafin. Diharapkan dapat memberikan asuhan keperarawatan yang optimal terutama intervensi pijat (massage) kepada lansia yang menderita rematik serta dapat mensosialisasikan keterampilan pijat (massage) kepada para lansia, sehingga mereka dapat secara mandiri melakukan pijat (massage) bila ada serangan nyeri tanpa harus membutuhkan bantuan tenaga kesehatan maupun keluarga.

\section{DAFTAR PUSTAKA}

Anas, Tamsuri. Konsep \& Penatalaksanaan Nyeri. Jakarta : EGC; 2009.

Chairuddin. Masuk ke alam bawah sadar, atasi masalah psikomatik. 2008 diakses tanggal 17 januari 2017 dari laman http: // hipnotis.net/?p=49.

Guyton \& Hall. Fisiologis kedokteran. Jakarta : EGC; 2009.

Nugroho dan Wahyudi. Keperawatan gerontik Edisi 2. Jakarta : EGC; 2012.

Potter, P.A \& Perry, A.G. Buku ajar fundamental keperawatan: konsep, proses, dan praktik. Jakarta: EGC; 2012.

World Health Organization. Rheumatoid arthritis. Diunduh: www.who. Rheumatoid Arthritis.com 